\title{
Does the Building Still Matter? Usage Patterns in New, Expanded, and Renovated Libraries, 1995-2002
}

\section{Harold B. Shill and Shawn Tonner}

Since the mid-1990s, more than 390 academic institutions have constructed new libraries or have expanded, renovated, or reconfigured an existing library. Given current concern about the future of libraries and the nature of space needs, it is important to know what impact these improvements have had on use of the physical library. Using responses from a 68 -item Web survey conducted in early 2003 , this article examines the impact of building improvements on usage of the physical facility. Recommendations for facility planning are offered, and implications for the "library as place" debate are explored. This report is a companion piece to an article published in the November 2003 issue.

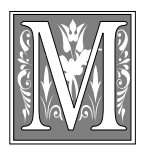

ore than 390 library building projects were completed in American and Canadian institutions of higher education between January 1995 and December 2002. The number of projects completed annually varied between eighteen and twentysix in most years, with a "low" of eleven completions in 2001 and a "peak" of thirty-nine finished projects in 2002.

Many new libraries opened in 2003, including major facilities at Marquette University, San Jose State University, Arcadia University, Columbia College, and the University of Georgia. More than fifty other projects are currently under construction, including new or expanded facilities at the University of Houston, Harvard University, Middlebury College, Santa Monica College, Indiana University-Southeast, Appalachian State University, and Cuesta College.
Design, fund-raising, and visioning activities are in progress at other institutions. Princeton University has engaged prominent architect Frank Gehry to design a $\$ 60$ million science library. Another renowned architect, Lord Norman Foster, is designing a $\$ 46$ million library for California State University-Channel Islands. The new University of California-Merced campus will have a 178,800-square-foot library when it opens in fall 2005. California State University-Monterey Bay is completing schematic design for a 200,000 -square-foot library scheduled to open in June $2007 .^{1}$

Despite this impressive level of building activity, however, librarians face a variety of challenges in making the case for physical improvements. These challenges, including growing student usage of Internet resources, off-site availability of

Harold B. Shill is Director of Capital College Libraries at Penn State Harrisburg and Penn State Schuylhill; e-mail: hbs2@psu.edu. Shawn Tonner is Director of the Hill Freeman Library E Spruill Learning Center at Reinhardt College; e-mail: sct@reinhardt.edu. 
electronic resources, institutional needs for technology upgrades in classroom buildings, and declining usage statistics, are examined in detail in the companion article, "Creating a Better Place: Physical Improvements in Academic Libraries, 1995-2002." 2 Scott Carlson's November 2001 Chronicle of Higher Education article, "The Deserted Library," ${ }^{3}$ suggested to academic administrators that libraries are becoming marginalized in the lives of some college students, while also noting cases of significant usage increases.

Many variables, including broader trends and local factors, contribute to usage levels within academic library buildings. Surprisingly, given the large cost of new and improved facilities, the relationship between facility quality and library usage has not been subjected to systematic, empirical analysis. The lack of evidence about this relationship is a serious gap in the profession's knowledge base. As a result, librarians are forced to rely on anecdotal evidence alone in making the case that major facility improvements will have a positive impact on library usage.

As reported in the companion article, the authors sent a 68-question survey to academic institutions that had recently built new libraries or significantly enhanced existing facilities in January 2003. The previous article discussed the nature of these physical improvements and identified trends in library design. The current study uses data from the same questionnaire to describe the impact of these improvements on usage of the physical facility. Its conclusions should enable librarians and facility planners to (1) project the likely impact of physical improvements on library usage and (2) determine the types of facility features most likely to contribute to major increases in building use.

An extensive literature review was provided in the earlier article and requires only one addition. Scott Bennett's Libraries Designed for Learning, published in late 2003, reported findings about space conceptualization and planning processes from a Web survey of library construction and renovation projects undertaken between 1992 and 2001. ${ }^{4}$

\section{Design and Methodology}

The earlier article describes the methodology of the study. Respondents were asked questions about:

- institutional characteristics;

- project-specific features (completion year, type of project, etc.);

- nature and extent of improvements made (seating, wiring, studies, etc.);

- presence of nonlibrary facilities;

- collection provisions;

- before-and-after quality changes (seating, layout, lighting, HVAC, etc.);

- usage before and after project completion.

The reader is referred to the companion article for details about the first six types of variables. Because the current article focuses on usage, the development and application of the "usage change" variable are described below.

In the survey, data on four usage variables-exit gate count, total circulation, in-house collection use, and reference transactions-were requested to determine (1) the extent to which facility improvements affected postproject usage and (2) the relationships between specific facility/institutional variables and changes in library use following project completion. The variables listed earlier were used as independent variables to determine their possible effects on postproject usage levels. The current study focuses on exit count as the key measure of facility use.

Usage changes were calculated by subtracting preproject totals for each usage indicator from the most recent postproject figures available. The remainder then was divided by the total from the preproject year, and a percentage of change was calculated. For example, if Hypothetical University opened a new Library $X$ during the 2000-2001 year, the following exit count calculation might occur:

150,000 exits recorded in 2001-2002

-96,000 exits recorded in 1999-2000

54,000 difference 


\begin{tabular}{|c|c|c|c|c|}
\hline \multicolumn{5}{|c|}{$\begin{array}{c}\text { TABLE } 1 \\
\text { Characteristics of Library Projects Included in Study }(n=182)\end{array}$} \\
\hline Variable & $\begin{array}{c}\text { Total } \\
\text { Projects } \\
(n=182)\end{array}$ & $\begin{array}{l}\text { Projects with } \\
\text { Exit Counts } \\
(\mathbf{n}=90)\end{array}$ & $\begin{array}{c}\text { Percent of } \\
\text { Projects in } \\
\text { Study }\end{array}$ & $\begin{array}{c}\text { Percent of } \\
\text { Projects with } \\
\text { Exit Counts }\end{array}$ \\
\hline \multicolumn{5}{|l|}{ Institution Type } \\
\hline Public & 118 & 61 & $64.8 \%$ & $67.8 \%$ \\
\hline Private & 64 & 29 & 35.2 & 32.2 \\
\hline \multicolumn{5}{|l|}{ Carnegie Classification } \\
\hline Associate & 21 & 15 & $11.4 \%$ & $16.7 \%$ \\
\hline Baccalaureate & 27 & 10 & 14.8 & 11.1 \\
\hline Master's & 51 & 29 & 27.8 & 32.2 \\
\hline Doctoral & 42 & 22 & 23.3 & 24.4 \\
\hline Branch/undergraduate & 20 & 5 & 10.8 & 5.6 \\
\hline Medical & 12 & 6 & 6.8 & 6.7 \\
\hline Law & 9 & 3 & 5.1 & 3.3 \\
\hline \multicolumn{5}{|l|}{ Project Type } \\
\hline New & 53 & 30 & $29.1 \%$ & $33.3 \%$ \\
\hline New, multipurpose & 31 & 12 & 17.0 & 13.3 \\
\hline Addition & 5 & 5 & 2.9 & 5.6 \\
\hline Addition/renovation & 73 & 31 & 40.0 & 34.4 \\
\hline Other & 20 & 12 & 11.0 & $13.3 *$ \\
\hline \multicolumn{5}{|l|}{ Completion Year } \\
\hline 1995 & 23 & 9 & $12.6 \%$ & $10.0 \%$ \\
\hline 1996 & 19 & 11 & 10.4 & 12.2 \\
\hline 1997 & 18 & 7 & 9.9 & 7.8 \\
\hline 1998 & 23 & 16 & 12.6 & 17.8 \\
\hline 1999 & 21 & 11 & 11.5 & 12.2 \\
\hline 2000 & 27 & 18 & 14.8 & 20.0 \\
\hline 2001 & 12 & 3 & 6.6 & 3.3 \\
\hline 2002 & 39 & 15 & $21.4^{*}$ & 16.7 \\
\hline
\end{tabular}

54,000 difference / 96,000 preproject total $=56.3 \%$ increase

In the case of new libraries, the most recent full preproject year before the new library was occupied was used as the baseline period for this calculation. Actual "move years" were avoided to eliminate data contamination from the mixing of old and new library figures.

For addition and renovation projects, usage is normally depressed during the construction period as users seek a quieter working environment. For these libraries, the full year two years prior to project completion was used as the baseline year. Postproject usage changes would be exaggerated if a midconstruction baseline year were used, so earlier years were selected to elicit a more normal measure of preproject usage.

\section{Study Findings}

Even though 171 respondents completed most survey questions, the number of usable responses for the four facility usage questions ranged from 106 libraries (circulation) to 45 libraries (inhouse collection use). Usable exit count data were supplied by ninety libraries ( $25.3 \%$ of the overall survey population and $49.5 \%$ of the participating libraries). Several reasons for nonresponses on the usage questions were identified, including: 


\begin{tabular}{|lcccc|}
\hline \multicolumn{5}{|c|}{ TABLE 2 } \\
Postproject Changes in Facility Use \\
by Key Use Measures \\
\hline \hline Use Measure & \% Increase & Highest & Lowest & Median \\
\hline Exit Count & $80.0 \%$ & $+1012.0 \%$ & $-40.8 \%$ & $+37.4 \%$ \\
Circulation & 44.8 & +3350.6 & -69.3 & -4.1 \\
Reference & 40.1 & +162.4 & -73.3 & -21.4 \\
In-house Use & 26.7 & +565.5 & -63.7 & -23.0 \\
\hline
\end{tabular}

ing exit count data, the major dependent variable used in this report, are described in table 1.

Table 1 provides a general breakdown of responding libraries by institution type, modified Carnegie classification, project type, and completion year. It con-

- lack of complete historical data on these variables, particularly from the preproject period;

- data collection gaps (malfunctioning exit gate counter, etc.) that made comparison of recent and older data unreliable;

- changes in data-recording practices;

- recent completion dates (fall 2002, etc.) that precluded the comparison of pre- and postproject data during the spring 2003 data analysis period;

- respondent data collection burden. Key characteristics of the overall respondent population and those libraries provid- firms that the percentage of libraries providing exit count data approximates the overall distribution of library projects within these categories.

The resulting data were exported initially from the SSRI database into an Excel spreadsheet for preliminary analysis and assessment of frequency distributions, then later exported into SPSS (Statistical Package for the Social Sciences) for significance testing. The statistical measures used to determine the existence and strength of relationships are described in the findings section.

Pre- and postproject facility usage (exit count) findings are reported below in the

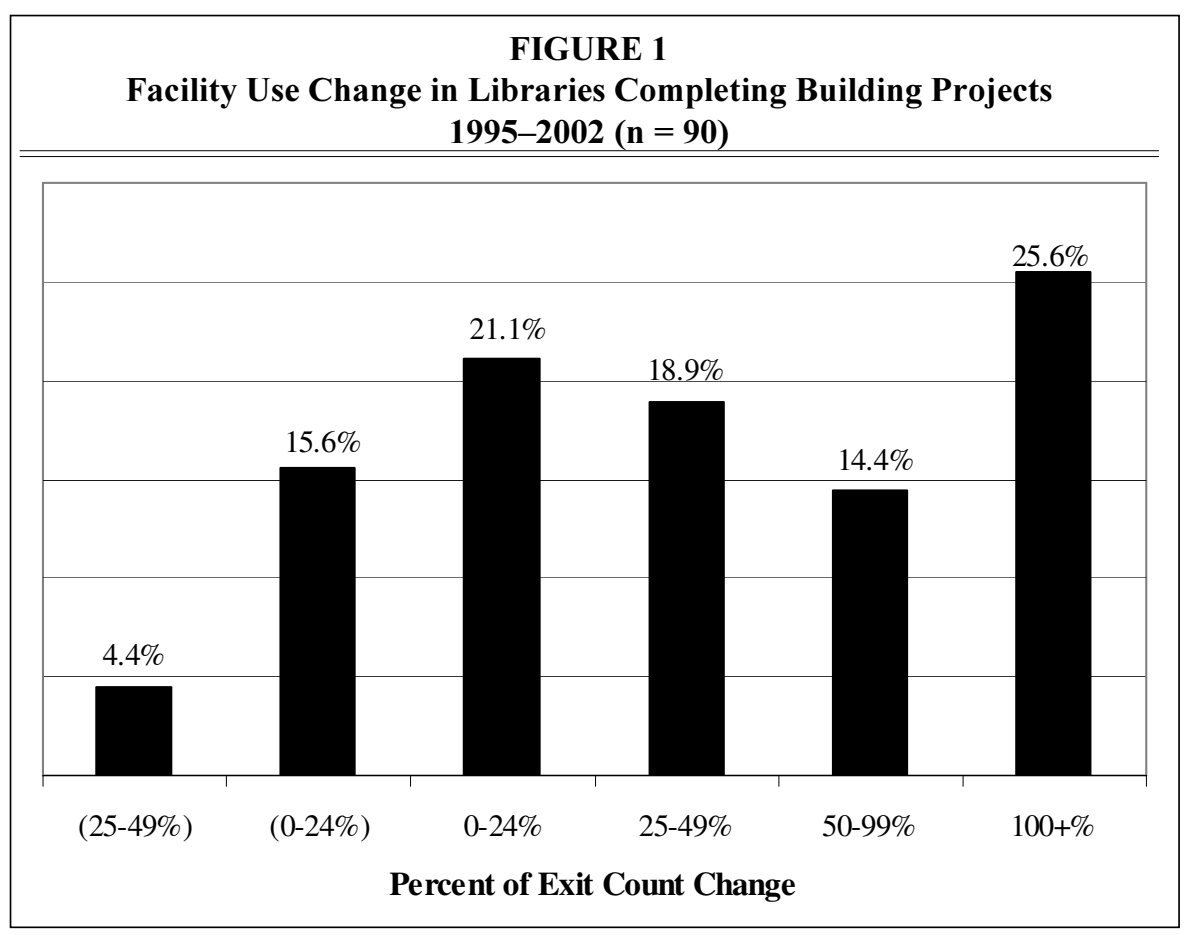




\section{TABLE 3}

\section{Libraries Reporting 200\% Postproject Increases in Facility Use}

\begin{tabular}{llcc} 
Library & \multicolumn{1}{c}{ Project Type } & $\begin{array}{c}\text { Completion } \\
\text { Date }\end{array}$ & $\begin{array}{c}\text { Exit Count } \\
\text { Change (\%) }\end{array}$ \\
\hline Univ. of San Francisco-Law & New & 2000 & 1012.0 \\
Arkansas Tech University & New multipurpose & 1999 & 525.4 \\
Williams College-Science & New multipurpose & 2000 & 386.5 \\
Trevecca Nazarene College & New & 2000 & 381.7 \\
Green River Comm. College & New multipurpose & 1996 & 268.6 \\
Mount Union College & Addition \& renovation & 2000 & 251.7 \\
Front Range Comm. College & New, joint use facility & 1998 & 232.5 \\
St. Martin's College & New & 2000 & 203.9 \\
*Note: Respondents have agreed to the publication of these data & & \\
\hline
\end{tabular}

following six sections: general project characteristics; technology; user space; collection provisions; nonlibrary facilities; and facility quality. Relationships between specific features and postoccupancy usage are explored. Correlations between specific characteristics and changes in postproject usage patterns are then discussed. A final section summarizes the major findings about the impact of facility improvements on library usage, indicates their significance for academic library planning, and suggests directions for future research.

Summary data for overall facility use (exit count) and the three other usage variables are reported in table 2. Although this article focuses primarily on exit count, overall usage change findings for circulation, in-house use, and reference activity are included here to allow preliminary comparisons of project impact on several measures of facility use.

The data in table 2 confirm that 80 percent $(n=72)$ of the ninety libraries supplying usable before-and-after exit count data increased their facility use following project completion, whereas nearly onehalf of those libraries reported circulation growth. Reference and in-house collection use declines were proportionately less than those reported for the whole population of ACRL, ARL, and AAHSL libraries during the study period. The findings in table 2 indicate that, in general, building improvements had a greater overall impact on basic facility use (gate count) than on circulation, reference transaction volume, and inhouse collection use.

As table 2 confirms, actual changes in exit count ranged from a 40.8 percent drop in usage to an increase slightly greater than 1000 percent. The median increase across all facilities providing usable preand postproject exit count data was 37.4 percent. The overall exit count data indicate that, in general, students are using new and improved libraries at levels greater than their use of preproject library facilities.

Because this article focuses primarily on use of the physical facility, rather than on collection use or services (circulation, reference, etc.), primary attention will be focused on the before-and-after facility usage (exit or gate count) data in this analysis. Figure 1 provides a more detailed breakdown of postproject exit count changes.

Although 80 percent of the responding libraries experienced some degree of postoccupancy usage growth, figure 1 shows that usage change varied widely across six level-of-change categories. In some cases, that usage increase has been profound. Whereas 25.6 percent $(n=23)$ of the postproject libraries experienced usage increases of 100 percent of more, 8.9 percent $(n=8)$ of the responding libraries (not shown in figure 1) reported usage increases actually exceeding 200 percent. 
The most dramatic exit count increase was reported by the University of San Francisco's Dorraine Zief Law Library, a new facility opened in 2000. That facility's 1012.0 percent increase has been confirmed with library officials. ${ }^{5}$ The data reflect a change from 30,809 annual users in the former library to more than 342,593 users in the new building in 2001-2002. Given an enrollment of 670 FTE students in the law school, this usage level is particularly impressive. Other usage increases exceeding 200 percent are reported in table 3 .

Table 3 lists the libraries reporting the greatest levels of postproject exit count change. However, although the preceding tables and figures confirm the general tendency toward postproject usage increases and provide some evidence of major usage growth, they do not identify either the types of projects or the specific enhancements most likely to stimulate building use.

In the following sections, the investigators will examine the relationship between specific facility features and postproject usage more closely. Chi-square tests are used to indicate where a relationship exists between a specific project attribute and postproject usage. Other statistical techniques are employed later in this analysis to determine the strength of any existing relationships between specific attributes and postoccupancy usage levels.

Because this study explores new ground and has practical implications, some usage-related findings for specific variables will be presented even when they are not statistically significant. The characteristics of libraries reporting the greatest increases $(100 \%+)$ in postproject usage also will be examined.

\section{Findings: General Characteristics}

Respondents were asked questions about the type of project done at their libraries, completion dates, public/private affiliation, facility size, the library's campus location, and shared usage with other campus operations. The investigators also determined the Carnegie classification for each library's host institution. Postproject usage change findings for these questions are presented below.

\section{Project Types}

Responses from the 182 libraries participating in the survey were placed into five "type of project" categories: new, standalone libraries (29.8\%); new libraries in multipurpose facilities (13.3\%); addition and renovation projects ( $42.0 \%)$; additions only $(2.8 \%)$; and "other" project types $(12.1 \%)$. The "other" category consists mainly of renovation-only projects. Changes in postproject facility usage from the ninety libraries providing usable exit count data are shown in table 4.

It was anticipated that new libraries and libraries in new, multipurpose facilities would show greater increases in usage than addition, renovation, and "other" project types. In fact, thirty-five of the forty-two new and new, multipurpose facilities $(83.3 \%)$ did report ex-

\begin{tabular}{|c|c|c|c|c|c|c|c|}
\hline \multicolumn{8}{|c|}{$\begin{array}{l}\text { TABLE } 4 \\
\text { Project Type and Changes in Postproject Facility Use }(n=90)\end{array}$} \\
\hline $\begin{array}{l}\text { Type of Facility } \\
\text { Project }\end{array}$ & $(25-49 \%)$ & $\begin{array}{r}\text { Exit } \\
(0-24 \%)\end{array}$ & $\begin{array}{l}\text { Count } \\
0-24 \%\end{array}$ & $\begin{array}{l}\text { Change } \\
25-49 \%\end{array}$ & $50-99 \%$ & $100+\%$ & Total \\
\hline New library & 2 & 3 & 5 & 6 & 5 & 9 & 30 \\
\hline New, multipurpose & 0 & 2 & 2 & 3 & 1 & 4 & 12 \\
\hline Addition only & 0 & 0 & 3 & 2 & 0 & 0 & 5 \\
\hline Addition/renovation & 0 & 8 & 5 & 5 & 5 & 8 & 31 \\
\hline Other & 2 & 1 & 4 & 1 & 2 & 2 & 12 \\
\hline Total & 4 & 14 & 19 & 17 & 13 & 23 & 90 \\
\hline
\end{tabular}


TABLE 5

Completion Date and Changes in Postproject Facility Use $(n=90)$

\begin{tabular}{lccccccc}
$\begin{array}{l}\text { Completion } \\
\text { Year }\end{array}$ & $\mathbf{( 2 5 - 4 9 \% )}$ & $\mathbf{( 0 - 2 4 \% )}$ & $\mathbf{0 - 2 4 \%}$ & $\mathbf{2 5}-\mathbf{4 9 \%}$ & $\mathbf{5 0 - 9 9 \%}$ & $\mathbf{1 0 0 + \%}$ & Total \\
\hline 1995 & 2 & 3 & 0 & 4 & 0 & 0 & $\mathbf{9}$ \\
1996 & 0 & 0 & 2 & 2 & 3 & 4 & $\mathbf{1 1}$ \\
1997 & 0 & 2 & 1 & 2 & 2 & 0 & $\mathbf{7}$ \\
1998 & 1 & 3 & 4 & 1 & 4 & 3 & $\mathbf{1 6}$ \\
1999 & 1 & 2 & 2 & 2 & 1 & 3 & $\mathbf{1 1}$ \\
2000 & 0 & 1 & 7 & 3 & 0 & 7 & $\mathbf{1 8}$ \\
2001 & 0 & 0 & 0 & 1 & 0 & 2 & $\mathbf{3}$ \\
2002 & 0 & 3 & 3 & 2 & 3 & 4 & $\mathbf{1 5}$ \\
\hline Total & $\mathbf{4}$ & $\mathbf{1 4}$ & $\mathbf{1 9}$ & $\mathbf{1 7}$ & $\mathbf{1 3}$ & $\mathbf{2 3}$ & $\mathbf{9 0}$ \\
& & & & & & &
\end{tabular}

panded usage, with 31.0 percent $(n=13)$ of them exceeding the 100 percent increase level. Addition/ renovation projects did not lag far behind, with 74.2 percent $(n=23)$ experiencing growth and 25.8 percent $(n=8)$ attaining the 100 percent increase level. Although projects in existing facilities were slightly more likely to record postproject usage declines, there was no statistically significant difference in exit count changes between these libraries and new facilities. In short, although the construction of a new building provides a "fresh start" unencumbered by obsolete features, significant usage increases also can result from space improvements in existing facilities.

\section{Completion Pattern}

Positive changes in postproject usage were expected to be greatest in library projects completed during the latter years of the study period. The number of reporting projects remained relatively stable from 1995 through 2000 but declined significantly in 2001. However, the number of project completions then rebounded to its highest level during the entire study period in 2002, with 21.4 percent of the 182 responding libraries completed in that year. Findings for the ninety libraries providing meaningful before-and-after exit count data are summarized in table 5 .

As table 5 indicates, thirty-two of the thirty-six projects $(88.9 \%)$ completed dur-

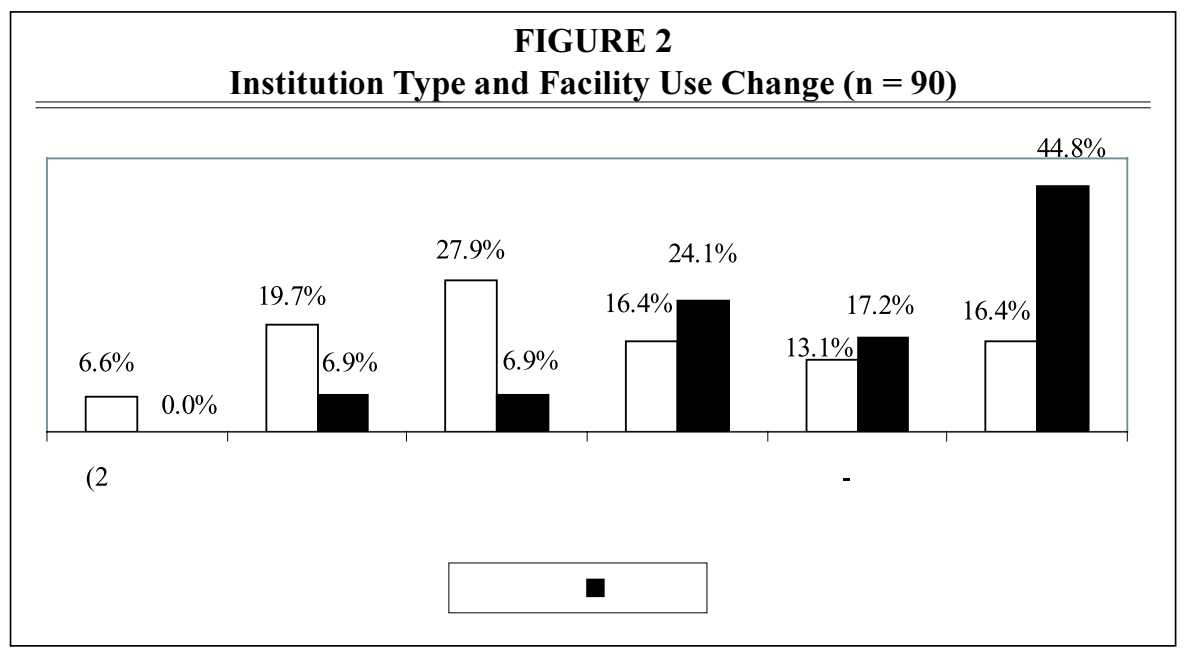


ing the 2000-2002 period, and providing usable before-and-after exit count data, showed usage increases. Most projects completed before 2000 still showed significant usage gains, with forty of the fifty-four pre-2000 libraries $(74.0 \%)$ reporting expanded use during the postproject measurement year. Interestingly, thirteen of the thirty-six projects $(36.1 \%)$ completed in 2000 or later reported $100 \%+$ increases in postproject usage. In contrast, five of the nine facilities completed in 1995 reported that their 2001-2002 usage level was less than the level reported for the last precompletion reporting period.

As expected, there was a slight tendency for projects completed more recently to show greater usage increases than projects completed earlier in the study period. However, the recency-usage relationship was not statistically significant ( $p=.160$ in a chi-square test). On balance, usage levels for more recently completed libraries are higher, but a clear majority of the libraries completed in the first half of the study period still showed 2001-2002 usage levels greater than those found for their preproject baseline year. In short, although newer libraries displayed slightly greater usage growth than those completed earlier in the study period, nearly 75 percent of the improved libraries are still experiencing usage levels exceeding those found before project initiation.

\section{Public and Private Projects}

The Carnegie Foundation for the Advancement of Teaching lists classifications for 3,941 higher education institutions on its Web site (www.carnegie.org). Public colleges and universities comprised 41.7 percent of the institutions listed, and private nonprofit and private for-profit institutions accounted for 42.7 and 15.6 percent, respectively, of the institutional population. ${ }^{6}$ Although public and private, non-profit institutions are represented almost equally in higher education, 64 percent of the responding libraries were in public institutions. In short, actual library building activity was proportion- ately greater in public institutions than in their private colleges and universities.

No initial assumptions were made about possible differences in postproject usage between public and private institutions. However, as figure 2 indicates, usage increases were found more consistently in private institutions than in public colleges and universities, with twentyseven of the twenty-nine improved libraries in private institutions (93.1\%) recording positive changes in postproject usage. However, 73.8 percent $(n=45)$ of the public institution libraries also experienced usage growth in the most recent measurement year. This finding is significant at the $p=.010$ level in a chi-square test.

In addition to showing a great probability of postproject usage increases, private institutions accounted for a somewhat disproportionate number of the "100 percent increasers." As the righthand bar in figure 2 confirms, thirteen of the twenty-nine private institution libraries $(44.8 \%)$ reported positive usage changes at this level. In contrast, just ten of the sixty-one public institutions (16.4\%) saw exit count increases of 100 percent, while 19.7 percent reported usage reductions of 0-24 percent and 6.6 percent experienced usage declines of 25-49 percent.

Although most public institution projects reported postproject usage increases, this significant difference between public and private institution libraries was not expected. One might speculate that liberal arts college libraries may require greater use of print library resources, but this finding requires further explanation. In summary, although both public and private institution libraries received heavier usage after project completion, nearly all facilities in private institutions received greater postproject use and almost half of them experienced a profound growth of 100 percent or more.

\section{Carnegie Class}

The investigators also wished to determine whether there were any significant differences in postproject facility usage among institutions in different Carnegie 


\section{TABLE 6}

Postproject Changes in Facility Use by Modified Carnegie Classification $(n=90)$

Modified Carnegie

Exit Count Change

$\begin{array}{llllllll}\text { Classification } & (25-49 \%) & (0-24 \%) & 0-24 \% & 25-49 \% & 50-99 \% & 100+\% & \text { Total }\end{array}$

\begin{tabular}{lrrrrrrr}
\hline Associate & 1 & 1 & 4 & 3 & 2 & 4 & $\mathbf{1 5}$ \\
Baccalaureate & 1 & 0 & 2 & 3 & 0 & 4 & $\mathbf{1 0}$ \\
Master's I or II & 1 & 4 & 6 & 6 & 7 & 5 & $\mathbf{2 9}$ \\
Doctoral & 0 & 2 & 7 & 5 & 3 & 5 & $\mathbf{2 2}$ \\
Branch/undergrad. & 0 & 3 & 0 & 0 & 0 & 2 & $\mathbf{5}$ \\
Medical & 1 & 2 & 0 & 0 & 1 & 2 & $\mathbf{6}$ \\
Law & 0 & 2 & 0 & 0 & 0 & 1 & $\mathbf{3}$ \\
\hline Total & $\mathbf{4}$ & $\mathbf{1 4}$ & $\mathbf{1 9}$ & $\mathbf{1 7}$ & $\mathbf{1 3}$ & $\mathbf{2 3}$ & $\mathbf{9 0}$
\end{tabular}

classes, regardless of public or private affiliation. In order to facilitate statistical analysis, they collapsed similar Carnegie classes (Baccalaureate-Liberal Arts with Baccalaureate-General, Master's I with Master's II, etc.). In addition, they devised a separate category of "branch or undergraduate library" to allow for possible differences in usage patterns within subject- or clientele-focused facilities on multilibrary campuses.

Doctoral and master's institutions completed proportionately more projects during the study period, in relation to their numbers in higher education, than other types of institutions did. Although comprising just 6.6 and 15.5 percent, respectively, of all colleges and universities listed by the Carnegie Foundation for the Advancement of Teaching in 2000, doctoral and master's institutions accounted for
23.5 and 27.4 percent, respectively, of the 182 libraries responding to the survey.

Table 6 shows the distribution, by modified Carnegie class, of participating libraries that were able to provide comparable before-and-after exit count data.

Most libraries in the four larger Carnegie classes reported usage increases, with the "increasers" ranging from twenty-four of twenty-nine libraries $(82.8 \%)$ for master's institutions to twenty of twenty-two libraries $(90.9 \%)$ for doctoral institutions. Declining usage was concentrated among branch/undergraduate, medical, and law libraries, but their numbers are too small to permit any inferences. In fact, the professional school libraries displayed a slight tendency to cluster toward the extremes of large increases or actual declines. As a result of these findings, the investigators have con-

TABLE 7

Building Size and Changes in Postproject Facility Use $(n=90)$

\begin{tabular}{lccccccc}
$\begin{array}{l}\text { Square Footage } \\
\text { in Facility }\end{array}$ & $\mathbf{( 2 5 - 4 9 \% )}$ & $\mathbf{( 0 - 2 4 \% )}$ & $\mathbf{0 - 2 4} \%$ & $\mathbf{2 5}-\mathbf{4 9 \%}$ & $\mathbf{5 0 - 9 9 \%}$ & $\mathbf{1 0 0 + \%}$ & Total \\
\hline$<20,000$ & 1 & 3 & 2 & 1 & 0 & 1 & $\mathbf{8}$ \\
$20,000-49,999$ & 0 & 1 & 2 & 4 & 2 & 6 & $\mathbf{1 5}$ \\
$50,000-74,999$ & 2 & 2 & 0 & 4 & 2 & 6 & $\mathbf{1 6}$ \\
$75,000-99,999$ & 0 & 1 & 3 & 1 & 3 & 4 & $\mathbf{1 2}$ \\
$100,000-149,999$ & 1 & 1 & 3 & 4 & 1 & 0 & $\mathbf{1 0}$ \\
$150,000-199,999$ & 0 & 1 & 1 & 1 & 2 & 1 & $\mathbf{6}$ \\
$>200,000$ & 0 & 5 & 8 & 2 & 3 & 5 & $\mathbf{2 3}$ \\
\hline Total & $\mathbf{4}$ & $\mathbf{1 4}$ & $\mathbf{1 9}$ & $\mathbf{1 7}$ & $\mathbf{1 3}$ & $\mathbf{2 3}$ & $\mathbf{9 0}$ \\
\hline
\end{tabular}


TABLE 8

Campus Location and Postproject Facility Use $(\mathbf{n}=90)$

\begin{tabular}{lccccccc}
$\begin{array}{l}\text { Library Location } \\
\text { on Campus }\end{array}$ & $\mathbf{( 2 5 - 4 9 \% )}$ & $\mathbf{( 0 - 2 4 \% )}$ & $\mathbf{0 - 2 4 \%}$ & $\mathbf{2 5}-\mathbf{4 9 \%}$ & $\mathbf{5 0 - 9 9 \%}$ & $\mathbf{1 0 0 + \%}$ & Total \\
\hline Central & 2 & 9 & 13 & 10 & 8 & 12 & $\mathbf{5 4}$ \\
Neutral & 1 & 0 & 3 & 6 & 2 & 5 & $\mathbf{1 7}$ \\
Peripheral & 1 & 5 & 3 & 1 & 3 & 6 & $\mathbf{1 9}$ \\
\hline Total & $\mathbf{4}$ & $\mathbf{1 4}$ & $\mathbf{1 9}$ & $\mathbf{1 7}$ & $\mathbf{1 3}$ & $\mathbf{2 3}$ & $\mathbf{9 0}$ \\
\hline
\end{tabular}

cluded that there is no apparent relationship between the level of degrees offered and postproject usage patterns.

\section{Library Size}

There was a significant overall increase in the size of physical library facilities as a result of building projects. Prior to completing their facility projects, 53.8 percent $(n=98)$ of the 182 responding libraries reported having less than 50,000 square feet of space, whereas only 28.0 percent $(\mathrm{n}=$ 51) fit into this size category afterward. In contrast, the number of libraries with space exceeding 200,000 square feet increased from 10.9 percent before the project to 25.3 percent following completion. The impact of facility size on postproject building usage is described in table 7.

The investigators made no assumptions about the possible impact of facility size on usage of postproject libraries. Because twelve of the thirty-one libraries in the 20,000-74,999 square foot range (38.7\%) experienced $100 \%$ increases, there may be a slight tendency toward greater usage of smaller facilities, but it is not statistically significant. Moreover, this finding could reflect a larger proportional increase in library space resulting from the replacement or expansion of very small facilities. However, facility size alone does not appear to be a significant factor affecting postproject usage patterns.

\section{Campus Location}

Most (62.1\%) of the 182 responding librarians indicated that their libraries occupied a central location on campus, whereas 18.7 percent reported a neutral location and 19.2 percent a peripheral location. Facility siting can be a major concern on campuses where existing buildings occupy all of the prime locations. However, as table 8 indicates, there was no statistically significant relationship between library siting and postproject usage patterns among the ninety libraries providing before-and-after exit count data.

Curiously, libraries with a peripheral location had the highest percentages of both 100 percent increases in use and postproject declines, with six of the nineteen peripheral projects ( $31.6 \%$ each) falling into the extreme-usage categories. Because responses to other proximity questions confirmed that most libraries are located within a quarter mile of parking lots, classroom buildings, and student centers, the investigators concluded that physical location did not have a significant overall impact on library building usage. Proximity to dormitories and other student residences appears to have had a slight positive influence, but it was not statistically significant.

\section{Library and Nonlibrary Uses}

Historically, library buildings have been built primarily to accommodate library collections, services, and operations, rather than to provide shared space for the library and other, nonlibrary units. The major exception to that tendency has been the location of subject-specialized branch libraries (music, science, engineering, etc.) in the same building with faculty offices and classrooms supporting those disciplines.

In recent years, however, many academic institutions have combined new or expanded library buildings with space for other campus operations. Because the presence of nonlibrary facilities could af- 


\begin{tabular}{|c|c|c|c|c|c|c|c|}
\hline \multicolumn{8}{|c|}{$\begin{array}{c}\text { TABLE } 9 \\
\text { Percent of Building Allocated for Library Functions and Changes in } \\
\text { Postproject Facility Use }(n=90)\end{array}$} \\
\hline $\begin{array}{l}\text { Percent for } \\
\text { Library Use }\end{array}$ & $(25-49 \%)$ & $\begin{array}{r}\text { Exi } \\
(0-24 \%)\end{array}$ & $\begin{array}{l}\text { it Count } \\
0-24 \%\end{array}$ & $\begin{array}{l}\text { Change } \\
25-49 \%\end{array}$ & $50-99 \%$ & $100+\%$ & Total \\
\hline$>25 \%$ & 1 & 2 & 0 & 0 & 0 & 1 & 4 \\
\hline $25-49 \%$ & 0 & 1 & 1 & 0 & 0 & 0 & 2 \\
\hline $50-74 \%$ & 0 & 2 & 1 & 2 & 1 & 2 & 8 \\
\hline $75-90 \%$ & 0 & 2 & 2 & 2 & 2 & 7 & 15 \\
\hline $90-99 \%$ & 3 & 5 & 5 & 5 & 5 & 8 & 31 \\
\hline $100 \%$ & 0 & 2 & 10 & 8 & 5 & 5 & 30 \\
\hline Total & 4 & 14 & 19 & 17 & 13 & 23 & 90 \\
\hline
\end{tabular}

fect postproject usage levels, the investigators were interested in seeing whether postproject usage was affected by (1) the relative percentage of the facility allocated for library functions and (2) the presence of specific types of nonlibrary facilities.

The following nonlibrary facilities were most frequently included in the 173 libraries answering this question:

- conference rooms $(82.7 \% ; \mathrm{n}=143)$; 121);

- general computer labs $(69.9 \%$; $\mathrm{n}=$

- seminar rooms (53.2\%; $\mathrm{n}=92)$;

- multimedia production centers $(45.1 \% ; \mathrm{n}=78)$;

- snack bars or cafes $(32.4 \% ; n=56)$;

- general use classrooms (31.8\%;n=55);

- educational technology centers $(26.0 \% ; n=45)$;

- $\operatorname{art}$ galleries $(24.9 \% ; n=43)$;

- auditoriums $(20.2 \% ; \mathrm{n}=35)$;

- writing labs $(16.8 \% ; n=29)$.
It was hypothesized that usage within new, multipurpose buildings would increase more significantly than usage in other types of library projects because they would attract many users with nonlibrary needs in addition to those coming to use library space and resources.

As the data in table 9 confirm, there is no significant relationship between the proportion of building space allocated for library functions and postproject usage levels. In fact, there appears to be a tendency toward diminished usage among facilities allocating less than 25 percent of their space for library purposes, but the number of cases is too small to permit generalizations from this limited finding. In contrast, usage increases were found in 93.3 percent of the facilities devoted entirely to library use. However, the greatest concentration of 100 percent usage increases occurred in buildings assigning

TABLE 10

Premises Wiring Type and Postproject Changes in Facility Use $(n=90)$

Project Writing

Type

CAT-2

CAT-5

CAT-5E

CAT 5 Premium

CAT-6

Fiber-Optic

Total

Exit Count Change

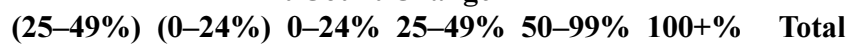

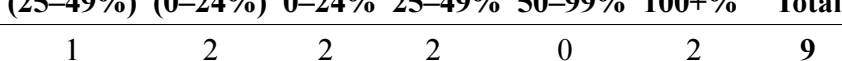

$\begin{array}{rrrrrrr}1 & 2 & 2 & 2 & 0 & 2 & \mathbf{9} \\ 1 & 10 & 9 & 5 & 7 & 7 & \mathbf{3 9} \\ 0 & 1 & 1 & 4 & 2 & 5 & \mathbf{1 3} \\ 0 & 1 & 1 & 1 & 0 & 2 & \mathbf{5} \\ 0 & 0 & 1 & 1 & 1 & 3 & \mathbf{6} \\ 2 & 0 & 5 & 4 & 3 & 4 & \mathbf{1 8} \\ \mathbf{4} & \mathbf{1 4} & \mathbf{1 9} & \mathbf{1 7} & \mathbf{1 3} & \mathbf{2 3} & \mathbf{9 0}\end{array}$


75 to 90 percent of their space for the library. It appears that there is no linear relationship between the proportion of a facility devoted to library functions and postproject usage, but usage growth occurs most frequently in all-library buildings and most dramatically in buildings where other units occupy 10 to 25 percent of the available space.

\section{Findings: Technology}

As student ownership of portable computing devices has grown, librarians have recognized the need to provide facilitywide network access for mobile users. According to a recent survey, 96 percent of all full-time Penn State undergraduates owned a computer in fall 2002, laptop ownership was increasing, and 15 percent owned a personal digital assistant (PDA) device. ${ }^{7}$ Although only 6.5 percent of the 182 responding libraries reported an institutional requirement for student computer ownership, the diffusion of computing devices is likely to accelerate as their use becomes more commonplace and prices trend downward.

This section examines the impact of various technology solutions-premises wiring systems, data ports, wireless systems, public access workstations, and instruction labs —on postproject usage.

\section{Premises Wiring Systems}

More than 83 percent (143 of 171) of the libraries responding to this question now have, at minimum, Unshielded Twisted
Pair (UTP) Category 5 (CAT-5) copper wiring throughout the building. In addition, 21.0 percent $(n=36)$ of the participating libraries reported that they now deliver "fiber to the desktop." These types of wiring infrastructure provide bandwidth sufficient to support high-speed downloads of textual, video, audio, and data files.

It was assumed that libraries providing higher-end wiring solutions would receive greater postoccupancy usage increases than those with less-robust network access. Possible associations between the type of wiring used throughout the facility ("premises wiring") and postproject usage are depicted in table 10.

Somewhat unexpectedly, the investigators found no relationship between the use of more robust types of wiring (fiber-optic, UTP Category 6, etc.) and postproject usage levels. Although twenty-two of the twenty-four libraries (91.7\%) deploying fiber-optic or CAT-6 cabling reported usage increases, their levels of usage change were not significantly different from those found for wiring categories with a lesser bandwidth. Although 33.3 percent $(n=3)$ of the CAT-2 libraries and 28.2 percent ( $n$ = 11) of the CAT-5 facilities reported postproject declines, the majority of libraries with those wiring types still reported usage increases, with several exceeding 100 percent. Although technology capabilities were expected to contribute to increased usage, it appears that wiring type

TABLE 11

Number of Data Ports and Changes in Postproject Facility Use $(\mathrm{n}=90)$

\begin{tabular}{lccccccc}
$\begin{array}{l}\text { Number Data } \\
\text { Ports }\end{array}$ & $\mathbf{( 2 5 - 4 9 \% )}$ & $\mathbf{( 0 - 2 4 \% )}$ & $\mathbf{0 - 2 4} \%$ & $\mathbf{2 5}-\mathbf{4 9 \%}$ & $\mathbf{5 0 - 9 9 \%}$ & $\mathbf{1 0 0 + \%}$ & Total \\
\hline$>50$ & 2 & 2 & 2 & 1 & 0 & 0 & $\mathbf{7}$ \\
$50-99$ & 1 & 2 & 2 & 3 & 2 & 1 & $\mathbf{1 1}$ \\
$100-249$ & 0 & 4 & 4 & 7 & 3 & 2 & $\mathbf{2 0}$ \\
$250-499$ & 0 & 2 & 1 & 4 & 1 & 10 & $\mathbf{1 8}$ \\
$500-999$ & 1 & 2 & 4 & 2 & 3 & 4 & $\mathbf{1 6}$ \\
$1000+$ & 0 & 2 & 6 & 0 & 4 & 6 & $\mathbf{1 8}$ \\
\hline Total & $\mathbf{4}$ & $\mathbf{1 4}$ & $\mathbf{1 9}$ & $\mathbf{1 7}$ & $\mathbf{1 3}$ & $\mathbf{2 3}$ & $\mathbf{9 0}$ \\
\hline Chi-square $=39.390$ & & $\mathrm{df}=25$ & $p=.034$ \\
\hline
\end{tabular}


TABLE 12

Extent of Wired Seating and Postproject Changes in Facility Use $(n=90)$

\begin{tabular}{|c|c|c|c|c|c|c|c|}
\hline $\begin{array}{l}\text { Percent Wired } \\
\text { Seats }\end{array}$ & $(25-49 \%)$ & $\begin{array}{r}\text { Ex } \\
(0-24 \%)\end{array}$ & $\begin{array}{l}\text { it Count } \\
0-24 \%\end{array}$ & $\begin{array}{l}\text { Change } \\
25-49 \%\end{array}$ & $50-99 \%$ & $100+\%$ & Total \\
\hline $0 \%$ & 2 & 0 & 2 & 3 & 2 & 2 & 11 \\
\hline $1-10 \%$ & 0 & 4 & 4 & 1 & 1 & 0 & 10 \\
\hline $11-24 \%$ & 0 & 2 & 4 & 2 & 1 & 4 & 13 \\
\hline $25-49 \%$ & 1 & 1 & 3 & 1 & 3 & 1 & 10 \\
\hline $50-74 \%$ & 1 & 0 & 1 & 1 & 2 & 4 & 9 \\
\hline $75-99 \%$ & 0 & 6 & 2 & 8 & 3 & 4 & 23 \\
\hline $100 \%$ & 0 & 1 & 3 & 1 & 1 & 8 & 14 \\
\hline Total & 4 & 14 & 19 & 17 & 13 & 23 & 90 \\
\hline Chi-square $=43.31$ & & $\mathrm{df}=30$ & $p=$. & 055 & & & \\
\hline
\end{tabular}

alone does not explain much of the change in postproject facility use.

\section{Data Ports and Wired Seating}

As higher-capacity wiring alone was not associated with increased usage, the investigators were interested to know whether the relative availability of network access points would influence postproject usage. Both wired and wireless access solutions were viewed as possible technology factors affecting facility usage.

Table 11 depicts the relationship between the number of wired data ports and postproject usage patterns. Prior to project completion, 107 of the 172 responding libraries $(62.2 \%)$ contained fewer than fifty network connections of any kind, including dedicated ports for office and OPAC computers. Following project completion, 51.7 percent of all responding libraries reported having 250 or more data ports.

As table 11 confirms, there is a statistically significant relationship (chi-square = 39.390, $p=.034$ ) between the number of data ports in a library facility and postproject usage. Of the libraries offering 250 to 499 data ports, 55.6 percent $(n=10)$ experienced usage increases exceeding 100 percent; 29.4 percent $(n=10)$ of the facilities with 500 or more data ports also surpassed the 100 percent benchmark. In contrast, only 7.9 percent $(n=3)$ of the libraries offering 249 or fewer data ports attained the 100 percent increase level.
Interestingly, the relative absence of data ports also appears to discourage library usage. Seven of the eighteen libraries $(38.9 \%)$ reporting fewer than 100 data ports experienced postproject declines in usage, whereas only 20 percent of the responding libraries reported drops in use. Clearly, the presence of abundant network access points is significantly related to postoccupancy usage patterns.

The number of data ports in a building also includes dedicated ports for public access workstations, service points, offices, instruction labs, and computer labs. In order to consider the impact of mobile, end-user ports separately from fixed network access points, the investigators asked that respondents indicate the percentage of wired public seats in the facility. The findings in this section include both open area and group study seating. Table 12 documents the relationship between wired public seating and facility use.

Because 25.6 percent $(n=23)$ of the responding libraries experienced a 100 percent increase in usage, one would expect most of the highly "wired" libraries to report major increases in postproject usage. As expected, eight (57.1\%) of the fourteen libraries with wired network access at all seating locations reported usage increases of 100 percent or more. Surprisingly, however, six $(26.1 \%)$ of the twentythree facilities in the 75 to 99 percent wired 
TABLE 13

Wireless Network Access and Changes in Postproject Facility Use $(n=90)$

\begin{tabular}{lccccccc}
$\begin{array}{l}\text { Wireless Access } \\
\text { Available? }\end{array}$ & $\mathbf{( 2 5 - 4 9 \% )}$ & $\mathbf{( 0 - 2 4 \% )}$ & $\mathbf{0 - 2 4} \%$ & $\mathbf{2 5}-\mathbf{4 9 \%}$ & $\mathbf{5 0 - 9 9 \%}$ & $\mathbf{1 0 0 + \%}$ & Total \\
\hline Yes & 0 & 7 & 12 & 12 & 10 & 9 & $\mathbf{5 0}$ \\
No & 4 & 7 & 7 & 5 & 3 & 14 & $\mathbf{4 0}$ \\
\hline Total & $\mathbf{4}$ & $\mathbf{1 4}$ & $\mathbf{1 9}$ & $\mathbf{1 7}$ & $\mathbf{1 3}$ & $\mathbf{2 3}$ & $\mathbf{9 0}$ \\
\hline
\end{tabular}

Chi-square $=12.093 \quad \mathrm{df}=5 \quad p=.034$

seating range encountered declines in postproject usage.

The chi-square finding of $p=.055$ in table 12 does not quite attain the $p<.05$ level indicating the presence of a statistically significant relationship between the extent of wired seating and postproject usage. However, it is significant, for planning purposes, that the majority of the completely wired libraries recorded postoccupancy usage gains exceeding 100 percent. It appears that an investment in ubiquitous or near ubiquitous wired network access in public seating areas contributes to increased levels of student facility use.

\section{Wireless Systems}

Wireless systems were rare in academic libraries before project completion, with 149 of the 171 responding libraries (87.1\%) lacking any wireless installation. In contrast, 57.9 percent of the participating libraries reported that wireless connectivity was available in their facility, to at least some degree, by early 2003. In many cases, wireless systems were installed after the building project was completed to complement an existing wired infrastructure. Wireless systems are now commonplace, but they are not found in all libraries undergoing a building improvement project since 1994.

The presence of wireless systems was expected to be associated with increased facility usage as students increasingly acquire wireless devices and demand wireless access. A chi-square test indicates that a significant relationship exists at the $p=.034$ level, but it is an inverse relationship.

Unexpectedly, table 13 shows that 100 percent increases were found more commonly in libraries without a wireless network, with only 18.0 percent $(n=9)$ of the wireless facilities and 35.0 percent $(n=14)$ of the nonwireless libraries showing increases of this magnitude. In contrast, table 13 also indicates that postproject usage

TABLE 14

Extent of Wireless Seating and Postproject Changes in Facility Use $(n=90)$

\begin{tabular}{lccccccc}
$\begin{array}{l}\text { Percent Wireless } \\
\text { Seating }\end{array}$ & $(\mathbf{2 5 - 4 9 \% )}$ & $\mathbf{( 0 - 2 4 \% )}$ & $\mathbf{0 - 2 4 \%}$ & $\mathbf{2 5}-\mathbf{4 9 \%}$ & $\mathbf{5 0 - 9 9 \%}$ & $\mathbf{1 0 0 + \%}$ & Total \\
\hline $0 \%$ & 4 & 7 & 7 & 6 & 3 & 15 & $\mathbf{4 2}$ \\
$1-10 \%$ & 0 & 2 & 0 & 2 & 0 & 0 & $\mathbf{4}$ \\
$11-24 \%$ & 0 & 0 & 2 & 0 & 2 & 0 & $\mathbf{4}$ \\
$25-49 \%$ & 0 & 0 & 1 & 2 & 0 & 0 & $\mathbf{3}$ \\
$50-74 \%$ & 0 & 1 & 1 & 1 & 0 & 1 & $\mathbf{4}$ \\
$75-99 \%$ & 0 & 0 & 3 & 0 & 0 & 2 & $\mathbf{5}$ \\
$100 \%$ & 0 & 4 & 5 & 6 & 8 & 5 & $\mathbf{2 8}$ \\
\hline Total & $\mathbf{4}$ & $\mathbf{1 4}$ & $\mathbf{1 9}$ & $\mathbf{1 7}$ & $\mathbf{1 3}$ & $\mathbf{2 3}$ & $\mathbf{9 0}$ \\
\hline
\end{tabular}




\begin{tabular}{|c|c|c|c|c|c|c|c|}
\hline \multicolumn{8}{|c|}{$\begin{array}{c}\text { TABLE } 15 \\
\text { Number of Public Access Workstations and Changes in Postproject Facility } \\
\text { Use }(n=90)\end{array}$} \\
\hline $\begin{array}{l}\text { Number of } \\
\text { Public Access } \\
\text { Workstations } \\
\end{array}$ & $(25-49 \%)$ & & $\begin{array}{c}\text { it Count } \\
0-24 \%\end{array}$ & $\begin{array}{l}\text { Change } \\
25-49 \%\end{array}$ & $50-99 \%$ & $100+\%$ & Total \\
\hline$>10$ & 2 & 1 & 0 & 1 & 1 & 2 & 7 \\
\hline $10-19$ & 1 & 4 & 3 & 2 & 0 & 3 & 13 \\
\hline $20-39$ & 0 & 1 & 2 & 6 & 3 & 4 & 16 \\
\hline $40-59$ & 0 & 2 & 2 & 1 & 4 & 5 & 14 \\
\hline 60-99 & 0 & 4 & 4 & 5 & 2 & 1 & 16 \\
\hline 100 or more & 1 & 2 & 8 & 2 & 3 & 8 & 24 \\
\hline Total & 4 & 14 & 19 & 17 & 13 & 23 & 90 \\
\hline
\end{tabular}

declines were concentrated more heavily in nonwireless libraries, with 27.5 percent $(\mathrm{n}=11)$ experiencing postproject reductions in usage, whereas only 14.0 percent $(n=7)$ of the wireless libraries suffered declines. Interestingly, usage changes in wireless-enhanced libraries cluster in the middle, with nonwireless libraries reporting both the greatest increases in use and the greatest declines.

The investigators also asked respondents to indicate the percentage of seats in their facilities offering wireless network access. The responses to that question are cross-tabulated with postproject usage data in table 14.

Once again, the findings are concentrated at the extremes. Only 17.9 percent $(n=5)$ of the libraries with wireless connectivity at all user seats reported 100 percent usage increases, whereas 35.7 percent $(n=15)$ of the libraries lacking any public wireless access reported increases at this level. However, those libraries without wireless network connections also confirmed the highest percentage of usage reductions, with eleven of forty-two libraries in this category $(26.2 \%)$ confirming declines in use. There is no statistically significant relationship between the percentage of user seats with wireless access and postcompletion usage levels.

Most library planners consider the inclusion of wireless network access to be desirable, as either the principal mode for end-user access or a complement to a wired network installation. However, as the ambiguous findings in this section indicate, there was no clear association between wireless connectivity and postproject usage among the libraries answering this question.

\section{Public Access Workstations}

Most enhanced libraries have expanded their number of public access workstations, whether in a conventional OPAC configuration or as an Information Commons. Prior to project completion, 84 of the 171 responding libraries (49.1\%) had fewer than ten public access workstations. After project completion, only 15.8 percent $(n=27)$ of these libraries still had fewer than ten public computers, whereas 67.8 percent $(n=116)$ of the postproject libraries had more than twenty public access computers, 41.0 percent $(n=70)$ had more than sixty public workstations, and 24.6 percent $(n=42)$ had more than one hundred such devices.

The presence of public access workstations would appear to be essential for encouraging student use because they are normally the starting point for catalog, database, and Internet research. In many libraries, students also are able to check e-mail and use applications software at public access workstations. Table 15 suggests the existence of a mild, positive re- 
lationship between the number of public workstations in a facility and increases in postproject usage, but it is not statistically significant.

Interestingly, one-third $(n=8)$ of the mostly larger libraries offering 100 or more public access computers experienced a 100 percent increase in usage following project completion. In comparison, 40 percent $(n=8)$ of the libraries providing nineteen or fewer public access computers suffered usage declines in the most recent measurement year. Even though digital divide concerns are diminishing in many academic libraries as computer prices come down to affordable levels for most students, an investment in public access computers (including loaner laptops) appears to have a positive influence on postproject usage.

\section{Library Instruction Facilities}

Information literacy instruction has become a major focus of academic library services today. Most respondents identified inadequate (or nonexistent) instruction facilities as a major shortcoming of the preproject library. The number of workstations and overall quality of a dedicated library instruction lab or electronic classroom can have a significant effect on instruction. Where more workstations are available, students are able to participate more actively in library instruction. This active learning experience should, in turn, result in more sophisticated use of library resources and, possibly, in more frequent use of the postproject library facility.

Prior to project completion, 67.9 percent $(\mathrm{n}=114)$ of the 171 responding libraries either lacked a dedicated instruction lab altogether or had a facility with only one instructor workstation. These libraries had a severely limited capacity to provide an active learning experience for students in the library instruction context.

After completion, 75.4 percent $(n=129)$ of the responding libraries had at least eleven workstations in their instruction labs, and 60.7 percent $(n=102)$ had more than twenty computers. In comparison, only 21.4 percent $(n=42)$ lacked an instruction lab or offered an instructional facility with only one workstation. Table 16 tests the hypothesis that the number of workstations in the instruction lab would be related to usage levels in the postproject library.

Unexpectedly, there was no statistically significant association between the number of computers in the instruction lab and postproject usage, with a $p=.415$ finding resulting from a chi-square test. Only seventeen of the fifty-eight libraries (29.3\%) providing usable before-and-after exit count data and offering twenty or more computers had usage increases of 100 percent or greater, whereas 25.6 percent $(n=$ 23) of the libraries with exit count data reported usage improvements at that level.

\begin{tabular}{|c|c|c|c|c|c|c|c|}
\hline \multicolumn{8}{|c|}{$\begin{array}{c}\text { TABLE } 16 \\
\text { Number of Instruction Lab Workstations and Postproject Changes in } \\
\text { Facility Use }(n=90)\end{array}$} \\
\hline $\begin{array}{l}\text { Number of } \\
\text { Workstations }\end{array}$ & $(25-49 \%)$ & $\begin{array}{r}E x \\
(0-24 \%)\end{array}$ & $\begin{array}{l}\text { it Count } \\
0-24 \%\end{array}$ & $\begin{array}{l}\text { Change } \\
25-49 \%\end{array}$ & $50-99 \%$ & $100+\%$ & Total \\
\hline 0 & 1 & 1 & 1 & 2 & 0 & 1 & 6 \\
\hline 1 & 0 & 4 & 1 & 0 & 1 & 1 & 7 \\
\hline $2-5$ & 0 & 0 & 1 & 0 & 0 & 0 & 1 \\
\hline $6-10$ & 0 & 0 & 0 & 1 & 1 & 0 & 2 \\
\hline $11-19$ & 1 & 2 & 2 & 3 & 4 & 4 & 16 \\
\hline 20-39 & 1 & 2 & 4 & 7 & 2 & 10 & 26 \\
\hline 40 or more & 1 & 5 & 10 & 4 & 5 & 7 & 32 \\
\hline Total & 4 & 14 & 19 & 17 & 13 & 23 & 90 \\
\hline
\end{tabular}


Usage increases were most apparent in libraries where instruction labs contained twenty to thirty-nine workstations, with 38.5 percent $(n=10)$ of the libraries experienced 100 percent usage gains. Six of the thirteen libraries $(46.2 \%)$ without an instruction lab or providing only an instructor workstation suffered postproject usage decline.

In short, although the actual number of workstations in the instruction lab may contribute to library use, it is not statistically associated with postcompletion usage. It is possible that hands-on experience in searching electronic resources may empower students to feel comfortable in conducting their research without coming to the library. However, table 16 does not address another possible relationship, that is, the linkage between instruction lab quality and usage levels. That relationship is examined in the quality improvement section of this article.

\section{Findings: User Space}

Typically, prior to initiating a building project, academic libraries are forced to cannibalize seating space to accommodate collection growth. Although this measure has been justified to maintain and preserve print and nonprint collections in the absence of other alternatives, it has affected library use by reducing the number and quality of spaces available for research and study. In many libraries, the extension of shelving to building perimeters has increased collection exposure to ultraviolet light while depriving users of seating space enhanced by natural light.

\section{Overall User Seating}

It was anticipated that most projects would expand the amount of general use (table, carrel, lounge) seats, and that expectation was confirmed by survey respondents. Logically, it also might be expected that the amount of seating in an enhanced facility would be related to increases in building usage.

However, a chi-square test (chi-square $=33.304, \mathrm{df}=30, p=.310$ ) confirmed that there is no relationship between the num- ber of seats in an improved library and postproject usage patterns. Given the broad variety of projects and institutions included in this study, this finding is not surprising. In smaller institutions, the replacement of a very undersized facility may result in significant usage increases, whereas postproject gains may be slighter in larger institutions already possessing significant library space. It is possible that smaller, more intimate facilities may appeal more to students than large facilities do. However, the data provided by this study do not allow further inferences. Tabular data about seating and usage levels will be provided upon request by the investigators.

It appears that a larger number of seats does not, in itself, produce significant increases in facility usage. Rather, it is more likely that usage increases in relation to the library's ability to seat a larger percentage of the student body at one time. However, respondents were not asked to provide exact seating capacities or enrollment figures, so further inferences are not possible from the data available.

\section{Group Study Seating}

Group study rooms are considered an essential component of contemporary library design, given the current emphasis on active and collaborative learning in higher education. Before project initiation, 45.6 percent $(n=78)$ of the 171 responding libraries did not have a single group study room and 80.7 percent $(n=138)$ had five or fewer studies.

The project investment in group study capacity was significant, but not as dramatic as might have been expected. Following completion, 44.5 percent $(n=76)$ of the responding libraries had eleven or more group study rooms, whereas 8.2 percent $(n=14)$ still did not provide any group studies and another 19.9 percent $(\mathrm{n}=34)$ had just one to five studies. Only 7.6 percent $(n=13)$ of the responding libraries provided more than thirty group study rooms. Still, the researchers anticipated that there would be a relationship between the number of group study 


\begin{tabular}{|c|c|c|c|c|c|c|c|}
\hline \multicolumn{8}{|c|}{$\begin{array}{c}\text { TABLE } 17 \\
\text { Number of Group Study Rooms and Changes in Postproject } \\
\text { Facility Use }(\mathrm{n}=\mathbf{9 0})\end{array}$} \\
\hline \multirow{2}{*}{$\begin{array}{l}\text { Group } \\
\text { Studies } \\
\end{array}$} & \multicolumn{6}{|c|}{ Exit Count Change } & \multirow[b]{2}{*}{ Total } \\
\hline & $(25-49 \%)$ & $(0-24 \%)$ & $0-24 \%$ & $25-49 \%$ & $50-99 \%$ & $100+\%$ & \\
\hline 0 & 0 & 2 & 0 & 1 & 0 & 1 & 4 \\
\hline $1-5$ & 2 & 3 & 3 & 3 & 1 & 2 & 14 \\
\hline $6-10$ & 0 & 4 & 5 & 4 & 3 & 11 & 27 \\
\hline $11-19$ & 1 & 4 & 4 & 8 & 5 & 7 & 29 \\
\hline $20-29$ & 1 & 1 & 2 & 1 & 3 & 0 & 8 \\
\hline $30-39$ & 0 & 0 & 2 & 0 & 1 & 0 & 3 \\
\hline 40 or more & 0 & 0 & 3 & 0 & 0 & 2 & 5 \\
\hline Total & 4 & 14 & 19 & 17 & 13 & 23 & 90 \\
\hline
\end{tabular}

rooms and postproject usage levels. The cross-tabulations for group study room numbers and postproject usage levels are presented in table 17.

Unexpectedly, table 17 indicates that there was no demonstrable relationship between the number of group study rooms and facility use. Only nine $(20 \%)$ of the libraries providing eleven or more group studies experienced a 100 percent usage increase. One library lacking any group study rooms whatsoever reported a 100 percent increase in usage, and two libraries providing just one to five group studies confirmed similar increases. The largest cluster of libraries with 100 percent increases was found for those offering six to ten group study rooms, rather than a larger number of collaborative study spaces.

These findings were unexpected because many libraries reported-in the survey, via e-mail, and in follow-up site visits-that they had not provided an adequate number of group study rooms to meet student demand. Further examination of these findings is required because they run counter to a major higher education trend. It is possible that the use of enrollment as a control variable might better indicate the impact of group study room numbers on physical library usage.

\section{Findings: Collection Variables}

The depletion of shelf space for print collections is a visible, readily understood ra- tionale for library facility expansion. When books cannot be re-shelved, students and faculty members complain, and higher education administrators understand that a space crisis has developed. Overcrowded shelves also may discourage facility use because they make both browsing and retrieval of known items more difficult.

Survey participants were asked to indicate the provisions their libraries had made for print collection growth during project planning. The investigators focused on three aspects of print collection planning-long-range stack capacity, use of compact storage, and reliance on offsite storage facilities-that could potentially affect facility usage, assuming that ease of access to print resources is a factor potentially affecting students' decisions to use library facilities.

\section{Print Growth Capacity}

To determine how effectively facility planners had addressed long-range collection needs, the investigators asked respondents to indicate a projected date of shelf space exhaustion for print collections at current acquisition rates. These projections incorporate shelf space in both conventional and compact shelving. Postproject usage levels are cross-tabulated with project shelf space exhaustion dates in table 18.

As indicated by a chi-square test (chisquare $=26.244, \mathrm{df}=30, p=.663$ ), there is no apparent relationship between shelving capac- 


\begin{tabular}{|c|c|c|c|c|c|c|c|}
\hline \multicolumn{8}{|c|}{$\begin{array}{l}\text { TABLE } 18 \\
\text { Projected Date of Shelf Space Exhaustion and Postproject Changes in } \\
\text { Facility Use }(n=87)\end{array}$} \\
\hline $\begin{array}{l}\text { Projected } \\
\text { Exhaustion } \\
\text { Date }\end{array}$ & $(25-49 \%)$ & $(0-24 \%)^{E}$ & $\begin{array}{l}\text { Exit Cou } \\
0-24 \%\end{array}$ & $\begin{array}{c}\text { nt Change } \\
25-49 \%\end{array}$ & $50-99 \%$ & $100+\%$ & Total \\
\hline $2003-05$ & 0 & 3 & 3 & 2 & 3 & 2 & 13 \\
\hline $2006-10$ & 0 & 4 & 7 & 2 & 2 & 1 & 16 \\
\hline $2011-15$ & 1 & 0 & 3 & 4 & 2 & 5 & 15 \\
\hline $2016-20$ & 2 & 4 & 1 & 4 & 1 & 6 & 18 \\
\hline $2021-25$ & 0 & 0 & 2 & 2 & 1 & 4 & 9 \\
\hline $2026-30$ & 0 & 0 & 1 & 1 & 1 & 1 & 4 \\
\hline $2031-$ & 1 & 2 & 2 & 1 & 3 & 3 & 12 \\
\hline Total & 4 & 13 & 19 & 16 & 13 & 22 & 87 \\
\hline
\end{tabular}

ity and postproject facility usage. Although 50 percent (6 of 12) of those facilities providing collection growth capacity until 2031 or later experienced 50 percent or greater usage increases, the investigators also found that one-quarter $(n=3)$ of the libraries providing this capacity experienced reductions in postproject usage. This somewhat ambiguous finding may reflect decreased usage of print materials. Although investing in long-term stack capacity appears wise for collection management, it does not appear to significantly affect facility usage.

\section{Compact Shelving Use}

Although it has traditionally been viewed as a high-density storage option for low- use materials, compact shelving has been employed in the University of Kentucky and Nova Southeastern University libraries, among others, to stretch shelving capacity and capture space for user seating, service points, and other needs. Slightly more than one-half of the responding libraries made some use of compact shelving, but only 12 percent $(n=20)$ of the 165 libraries answering this question used it for one-quarter or more of their collections. Cross-tabulation data on compact storage use and exit count are shown in table 19.

As table 19 confirms, most libraries providing exit count data did not use compact storage for a large part of their

TABLE 19

Percent of Collection in Compact Storage and Changes in Postproject Facility Use $(n=89)$

\begin{tabular}{lccccccc}
$\begin{array}{l}\text { Percent in } \\
\text { Compact } \\
\text { Storage }\end{array}$ & $\mathbf{( 2 5 - 4 9 \% )}$ & $\begin{array}{c}\text { Exit Count Change } \\
\text { (0-24) }\end{array}$ & $\mathbf{0 - 2 4} \%$ & $\mathbf{2 5}-\mathbf{- 4 9 \%}$ & $\mathbf{5 0 - 9 9 \%}$ & $\mathbf{1 0 0 + \%}$ & Total \\
\hline None & 3 & 6 & 8 & 8 & 6 & 8 & $\mathbf{3 9}$ \\
$1-10 \%$ & 1 & 3 & 4 & 6 & 3 & 4 & $\mathbf{2 1}$ \\
$10-24 \%$ & 0 & 3 & 3 & 2 & 2 & 7 & $\mathbf{1 7}$ \\
$25-49 \%$ & 0 & 1 & 1 & 1 & 1 & 2 & $\mathbf{6}$ \\
$50-74 \%$ & 0 & 1 & 1 & 0 & 1 & 1 & $\mathbf{4}$ \\
$75-99 \%$ & 0 & 0 & 1 & 0 & 0 & 1 & $\mathbf{2}$ \\
$100 \%$ & 0 & 0 & 0 & 0 & 0 & 0 & $\mathbf{0}$ \\
\hline Total & $\mathbf{4}$ & $\mathbf{1 4}$ & $\mathbf{1 8}$ & $\mathbf{1 7}$ & $\mathbf{1 3}$ & $\mathbf{2 3}$ & $\mathbf{8 9}$
\end{tabular}


collections. Also, as the chi-square results (chi-square $=10.153, \mathrm{df}=25, p=.996$ ) for this table indicate, there is no relationship between use of compact shelving and postproject facility use. Interestingly, 41.2 percent $(n=7)$ of the libraries housing 10 to 24.9 percent of their current collections in compact storage experienced 100 percent increases in postproject usage. This limited finding does suggest that a wellorganized, easily operated compact storage system does not discourage collection use. In fact, such a system may facilitate long-term collection access by permitting libraries to place their entire collections into one physical facility, rather than overcrowding conventional shelving or relying on off-site storage.

\section{Off-site Storage Use}

From the standpoint of user access, off-site storage is the least desirable of the major storage options. Most $(72.7 \%, \mathrm{n}=120)$ of the 165 libraries completing this question were able to avoid dependence on off-site storage. However, 15.2 percent $(n=25)$ of the responding libraries did rely on a remote site to store one-quarter or more of their print collection materials, indicating that their project did not permit (whether by design or accident) the placement of all collections in a facility permitting directuser access. The use of off-site collection storage facilities does not necessarily discourage facility use because it may enable the library to provide more on-site seating or otherwise deliver a more pleasing learning environment.

The findings indicate that off-site storage is not associated statistically with postoccupancy usage patterns. Only eighteen libraries using off-site storage also provided pre- and postproject usage data, and 38.9 percent $(n=7)$ of these libraries reported usage declines. Three libraries using off-site storage did experience 100 percent postproject increases in usage, but none of those libraries had more than 10 percent of their collections shelved in a remote location.

Off-site storage itself probably does not contribute directly to frequency of library facility use, particularly if low-use materials are selected carefully for that site. However, in many cases, libraries relying heavily on off-site storage have not provided sufficient shelf space to accommodate collection growth. This may mean that higher-use materials are stored in cramped spaces, thereby reducing ease of print collection use, which is still a major reason for visiting a physical library.

\begin{tabular}{|c|c|c|c|c|}
\hline \multicolumn{5}{|c|}{$\begin{array}{c}\text { TABLE } 20 \\
\text { Impact of Non-Library Facilities on Postproject Changes in Library Use } \\
\end{array}$} \\
\hline $\begin{array}{l}\text { Type of Nonlibrary } \\
\text { Facility Included } \\
\text { in Same Building } \\
\end{array}$ & $\begin{array}{c}50 \% \text { Use } \\
\text { Increases } \\
\text { with } \\
\text { Facility (n) } \\
\end{array}$ & $\begin{array}{c}50 \% \text { Use } \\
\text { Increases } \\
\text { without } \\
\text { Facility (n) }\end{array}$ & $\begin{array}{c}\% \text { of } 50 \% \\
\text { Increases } \\
\text { with } \\
\text { Facility }\end{array}$ & $\begin{array}{c}\% \text { of } 50 \% \\
\text { Increases } \\
\text { without } \\
\text { Facility }\end{array}$ \\
\hline General Computer Lab $(\mathrm{n}=68)$ & 26 & 10 & $38.2 \%$ & $45.5 \%$ \\
\hline Snack Bar/Café $(\mathrm{n}=31)$ & 12 & 24 & 38.7 & 40.7 \\
\hline General Classrooms $(n=35)$ & 16 & 20 & 45.7 & 36.4 \\
\hline Seminar Rooms $(n=47)$ & 21 & 15 & 44.7 & 34.9 \\
\hline Multimedia Prod. Center $(n=41$ & 1) 20 & 16 & 48.8 & 32.7 \\
\hline Auditorium $(\mathrm{n}=20)$ & 9 & 27 & 45.0 & 38.6 \\
\hline Conference Room $(\mathrm{n}=78)$ & 32 & 4 & 41.0 & 33.3 \\
\hline Art Gallery $(\mathrm{n}=23)$ & 12 & 24 & 52.2 & 35.8 \\
\hline Writing Lab $(n=20)$ & 11 & 25 & 55.0 & 35.7 \\
\hline Bookstore $(n=5)$ & 1 & 35 & 20.0 & 41.2 \\
\hline Research Institute $(n=6)$ & 2 & 34 & 33.3 & 40.5 \\
\hline Educational Tech.Center $(n=26$ & 6) 11 & 25 & 42.3 & 39.1 \\
\hline
\end{tabular}




\section{Findings: Nonlibrary Facilities}

As noted in table 4, new, stand-alone libraries comprise only 33.3 percent $(n=30)$ of the ninety libraries providing usable exit count data. New, multipurpose facilities (12 of the 90 facilities with meaningful exit count data) also are becoming increasingly popular as a means for institutional cost containment, and they may contribute to the creation of strategic partnerships potentially benefiting both the library and its coinhabitants. ${ }^{8}$ In other instances, inclusion of the library in a multipurpose facility may be the only politically viable strategy for securing institutional commitment toward a major facility enhancement.

The trend toward inclusion of nonlibrary facilities within the building has changed the character of recently improved libraries in significant ways. Rather than having a few nonlibrary units occasionally occupying space in the building, the physical library is increasingly becoming the home base for a wide variety of operations. As such, it is becoming a more complex facility that attracts students for multiple purposes and must accommodate the needs of nonlibrary units.

Table 20 lists twelve types of nonlibrary facilities found frequently in postproject buildings and shows possible associations between the presence of particular facilities and usage patterns. The first column lists the nonlibrary facility types and their frequency of occurrence (maximum $n=90$ ) in projects for which usable exit count data were available. The investigators focused on libraries experiencing 50 percent usage gains to provide a better indication of facility impact than would be possible by examining only the 100 percent increasers.

The second column indicates the number of libraries (maximum $n=36$ ) including a specific nonlibrary facility that experienced 50 percent or greater increases in postoccupancy usage. The third column lists the number of projects without that facility that reported 50 percent usage increases. The fourth and fifth columns indicate the percentage of libraries with and without a particular facility that reported 50 percent increases.
Conference rooms $(n=78)$ and general computer labs $(n=68)$ were found most frequently in postproject buildings providing before-and-after exit count data. As a result, they would be expected to show the greatest frequency among the thirty-six libraries experiencing 50 percent usage increases. That expectation is confirmed in the second column. However, because these types of facility were included most frequently in library improvement projects, their relative impact on usage is shown more clearly by the percentage data in the two right-hand columns than by the raw data in columns two and three.

Interestingly, writing labs and art galleries appear to be slightly associated with increases in postoccupancy usage, with more than one-half of the libraries including those nonlibrary facilities reporting 50 percent usage increases. Somewhat surprisingly, fewer facilities with general computer labs (38.2\%) experienced 50 percent postoccupancy usage growth than facilities without general computer labs (45.5\%).

General-use classrooms and seminar rooms appear to be slightly associated with higher increase levels, but there is no major usage difference between libraries with and without them. Somewhat unexpectedly, the presence of cafes and snack bars was not associated with increases in usage, despite their current popularity in library design.

The associations noted above are moderate tendencies based on a limited number of cases. None of these associations is statistically significant. On balance, there is no evidence that the presence of particular nonlibrary facilities has a significant impact on library exit counts. There may be good reasons for including various nonlibrary facilities in a project, but there is no indication from this study that their presence has a significant impact, either positive or negative, on facility usage.

\section{Findings: Facility Quality}

A final set of eleven questions addressed facility quality and librarian satisfaction with their libraries before and after project 
TABLE 21

Facility Features Rated "Excellent" by Respondents and Changes in Postproject Library Use

\begin{tabular}{|c|c|c|c|c|c|c|}
\hline $\begin{array}{l}\text { Facility Feature and } \\
\text { Number of Responses }\end{array}$ & $\begin{array}{c}25-49 \% \\
\text { Decrease } \\
(n=4)\end{array}$ & $\begin{array}{r}0-24 \% \\
\text { Decrease } \\
(n=14)\end{array}$ & $\begin{array}{c}0-24 \% \\
\text { Increase } \\
(n=19)\end{array}$ & $\begin{array}{c}25-49 \% \\
\text { Increase } \\
(n=17)\end{array}$ & $\begin{array}{r}50-99 \% \\
\text { Increase } \\
(n=13)\end{array}$ & $\begin{array}{c}100 \%+ \\
\text { Increase } \\
(n=23)\end{array}$ \\
\hline Facility Layout $(\mathrm{n}=42)$ & 2 & 4 & 4 & 10 & 9 & 13 \\
\hline Service Point Location $(n=47)$ & 7) 2 & 6 & 7 & 11 & 8 & 13 \\
\hline Instruction Lab $(\mathrm{n}=53)$ & 2 & 6 & 8 & 9 & 9 & 19 \\
\hline User Seating $(\mathrm{n}=66)$ & 2 & 9 & 11 & 13 & 11 & 20 \\
\hline Collection Storage $(n=49)$ & 1 & 6 & 11 & 9 & 7 & 15 \\
\hline Public Computers $(n=66)$ & 2 & 7 & 13 & 13 & 11 & 20 \\
\hline Telecommunications $(\mathrm{n}=58)$ & 2 & 8 & 10 & 9 & 9 & 20 \\
\hline Artificial Lighting $(\mathrm{n}=42)$ & 2 & 5 & 7 & 9 & 7 & 12 \\
\hline Natural Lighting $(n=62)$ & 1 & 8 & 10 & 11 & 10 & 22 \\
\hline $\operatorname{HVAC}(\mathrm{n}=26)$ & 1 & 2 & 5 & 3 & 6 & 9 \\
\hline Overall Ambience $(n=69)$ & 2 & 12 & 10 & 13 & 10 & 22 \\
\hline
\end{tabular}

completion. These respondent perceptions were expected to indicate the degree of facility improvement resulting from the project.

They also permitted cross-tabulation of quality ratings for particular facility features (seating, lighting, HVAC, etc.) with postproject usage to determine the relative impact of specific building elements on facility use.

Respondent assessments of the postproject library ambience were consistently positive, with 70.4 percent $(n=119)$ of 169 participants assigning an "excellent" rating and 94.3 percent $(n=160)$ considering the facility ambience either "excellent" or "very good." Significantly, no respondents rated their postproject facility ambience as either "fair" or "poor."

To assess the usage impact of specific facility improvements, regardless of project type, the investigators cross-tabulated respondent ratings of "excellent" with the usage change levels. The findings from this cross-tabulation are reported in table 21.

The excellence-usage relationships depicted in table 21 are significant for academic library planning. The left-hand column indicates the number of "excellent" ratings assigned to a particular facility feature, with 90 being the highest possible number. The remaining columns show varying degrees of postproject usage change for libraries where a specific feature was rated "excellent." If a particular facility feature were associated with high levels of usage, the investigators hypothesized that most libraries giving an "excellent" rating for that facility would experience 50 to 99 percent or $100+$ percent increases in postproject usage. In the $100+$ percent column, the maximum score would be 23 , indicating that all libraries experiencing usage increases at that level also would have assigned that facility variable an "excellent" rating.

It is apparent from the number of responses for specific features in the 100 percent column that most facilities with increases of that magnitude offer both an excellent ambience and excellent natural lighting for users. The quality of user seating, public access computers, and telecommunication infrastructure also is very important, with the instruction lab coming just slightly behind $(n=19)$ in association with 100 percent usage increases. Although all eleven facility features probably influence postproject use levels, the following features were considered "excellent" by 80 percent or more of the libraries experiencing 100 percent increases, with $n=$ 23 being the highest possible value: 
- overall facility ambience $(n=22)$;

- natural lighting $(\mathrm{n}=22)$;

- user seating quality $(\mathrm{n}=20)$;

- public access computers $(n=20)$;

- telecommunications infrastructure $(n=20)$;

- instruction lab $(\mathrm{n}=19)$.

These findings suggest that librarians and facility planners should place particular emphasis on the quality of these elements when planning library improvements.

The quality ratings are subjective assessments that can be treated as interval data, thereby enabling the investigators to examine relationships between the degree of postproject improvement and subsequent usage levels. In order to permit this type of analysis, the eleven quality variables were reverse coded with values ranging from 1 to 5 , with 1 being the lowest rating (poor) and 5 the highest rating (excellent) assigned.

Mean changes in quality assessment for each facility feature then were calculated by subtracting the mean of the preproject responses from the mean of the postoccupancy responses. A one-way Analysis of Variance (ANOVA) test was conducted to compare respondent perceptions of postproject feature quality with their perceptions of quality prior to project initiation.
For all eleven subjective quality measures, significant changes were found between respondents' pre- and postproject ratings of the measure. Table 22 shows the relative improvement in quality for these facility features resulting from the building project, as perceived by respondents. The greatest change in quality is shown for overall facility ambience, with a mean postproject improvement of 2.827 on a fiveitem scale. In other words, the mean improvement in ambience rating was just less than 3 points on a 5 -point scale, representing a change from "poor" (1) to "very good" (4) or from "fair" (2) to "excellent" (5).

Mean quality improvements of 2.5 or greater also were reported for user work space (2.748), the instruction lab (2.687), the telecommunications infrastructure (2.667), and public access workstations (2.599). The location of service points (1.670) and heating, ventilation, and air conditioning (HVAC) systems (2.068) received the lowest mean improvement ratings, but positive changes of this magnitude are still quite significant. On balance, the perception ratings indicate that facility quality was improved greatly as a result of the building project. Presumably, these acrossthe-board quality improvements should be associated with greater facility usage.

\begin{tabular}{|ccc|}
\multicolumn{3}{c|}{$\begin{array}{c}\text { TABLE } 22 \\
\text { Degree of Quality Improvement and Postproject Changes in } \\
\text { Facility Use, Based on Scale Rankings from 1 to 5 } \\
\text { (Postproject rating minus preproject rating) }\end{array}$} \\
\hline \hline & Mean Rating Improvement & Standard Deviation \\
\hline Facility Feature Rated & 2.122 & 1.400 \\
Quality of Layout & 1.670 & 1.312 \\
Quality of Service Point Location & 2.687 & 1.260 \\
Quality of nstruction Lab & 2.748 & 1.283 \\
Quality of User Work Space & 2.399 & 1.468 \\
Quality of Collection Storage & 2.599 & 1.161 \\
Quality of Public Workstations & 2.667 & 1.200 \\
Quality of Telecommunications & 2.117 & 1.358 \\
Quality of Artificial Lighting & 2.273 & 1.512 \\
Quality of Natural Light & 2.068 & 1.352 \\
Quality of HVAC & 2.827 & 1.212 \\
Quality of Ambience & & \\
\hline
\end{tabular}




\section{Strength of Relationships}

Earlier sections of this paper have explored the existence of possible relationships between specific variables and postproject usage levels. However, they have not specified either the strength or the direction of those relationships. This section examines those relationships more closely to determine which ones have the greatest impact on postproject usage.

Table 23 presents the bivariate correlation coefficients (Pearson's $r$ ) between key independent variables for the study and changes in postproject exit counts. The table includes both numerical indicators (number of data ports in the postproject facility, etc.) and subjective assessments of feature quality by respondents. Thirteen of these twenty-five independent variables were significantly related $(p<$ $.05)$ to increases in the postproject exit count, and some of the relationships are unusually strong.

Three variables attaining the $p<.05$ level of significance-institution type, number of data ports, and percentage of wired seats-were identified earlier as factors positively influencing postproject usage levels. These variables, and the ten additional quality variables identified as significant at the $p<.05$ level in table 23, are statistically correlated with increases in postcompletion facility use.

Two of these variables-quality of the instruction lab and quality of the telecommunication infrastructure-are related to factors examined earlier in this analysis. In those assessments, the investigators

\begin{tabular}{|c|c|c|}
\hline \multicolumn{3}{|c|}{$\begin{array}{c}\text { TABLE } 23 \\
\begin{array}{c}\text { Strength of Relationships between Specific Facility Features and Increases } \\
\text { in Postproject Usage }\end{array} \\
\end{array}$} \\
\hline Facility Feature & $\begin{array}{c}\text { Correlation } \\
(\text { Pearson's } r)\end{array}$ & $\begin{array}{l}\text { Significance } \\
\text { Level }(p=)\end{array}$ \\
\hline Quality of Instruction Lab & .399 & .000 \\
\hline Institution Type (public or private) & .384 & .000 \\
\hline Quality of Layout & .342 & .001 \\
\hline Number of Data Ports & .293 & .005 \\
\hline Quality of Public Access Workstations & .292 & .006 \\
\hline Quality of Natural Lighting & .282 & .007 \\
\hline Quality of User Work Space & .280 & .008 \\
\hline Quality of Telecommunication Infrastructure & .259 & .014 \\
\hline Quality of Overall Ambience & .244 & .020 \\
\hline Quality of Collection Storage & .236 & .026 \\
\hline Quality of HVAC System & .236 & .026 \\
\hline Percent of Wired Seats & .223 & .034 \\
\hline Quality of Service Point Locations & .221 & .038 \\
\hline Number of Workstations in Instruction Lab & .149 & .160 \\
\hline Quality of Artificial Lighting & .149 & .162 \\
\hline Percent of Facility Designated for Library Use & .110 & .302 \\
\hline Percent of Seats with Wireless Access & .064 & .551 \\
\hline Number of Group Study Rooms & .058 & .589 \\
\hline Location on Campus & .035 & .741 \\
\hline Availability of Wireless Network Access & -.029 & .787 \\
\hline Size of Library (gross square footage) & -.059 & .581 \\
\hline Collection Shelving Exhaustion Date & -.084 & .439 \\
\hline Use of Compact Shelving & -.098 & .360 \\
\hline Carnegie Classification (modified) & -.099 & .354 \\
\hline Number of General-use Seats & -.131 & .220 \\
\hline
\end{tabular}


did not find any relationship between the number of workstations in the instruction lab or the type of premises wiring and postproject usage levels. The correlational analysis confirms that such relationships do exist, when post- and preproject quality of these features is compared. For the number of data ports, this relationship is significant at the $p=.005$ level.

In fact, improvement in instruction lab quality emerges from table 23 as the single variable most closely related to increases in postproject usage, with a Pearson's $r$ value of .399 and a significance level of $p=.000$, even though the raw number of workstations in the lab did not have a significant impact on postcompletion usage. The correlational analysis also confirms the importance of private institutional affiliation as a powerful factor influencing usage levels, with a similar significance level of $p=.000$.

Several other quality variables-layout, public access workstations, natural lighting, and user work space-are significant at the $p<.010$ level. Effective layout and the use of abundant natural lighting are key characteristics of functional design. Their presence as factors related strongly to facility use is strong evidence that effective architectural design does influence postproject usage. The finding of a significant relationship $(r=.221 ; p=$ .038 ) between service point locations and facility use also indicates that the placement of service points is another key factor that should influence library design.

It was reported earlier that the number of public access workstations is associated with increased building usage, although the nature of that relationship was not specified. Table 23 confirms that both quantity and quality of a library's public access computers are related to facility usage. In short, library planners are well advised to place abundant, high-quality computers in a facility to encourage student use.

The number of general-use seats in an improved library facility was not associated with increased usage. However, table 23 indicates that the quality of user seating and work surfaces is a factor significantly affecting postoccupancy usage. It would ap- pear that comfortable seats, plus spacious, well-lit table and carrel surfaces, are factors that have a positive impact on usage of an enhanced facility. Those work spaces also should be wired, as the finding of a significant relationship $(r=.223 ; p=.034)$ between wired seating levels and postproject usage indicates.

Not surprisingly, improvement in the quality of a library's HVAC system also emerged from this analysis as a factor affecting facility use. Although the mean improvement in HVAC quality was 2.068 on a 5-point scale, study respondents were least satisfied with this factor among the eleven quality variables studied. However, where the improvement was significant, better HVAC quality was associated with greater increases in postoccupancy usage.

It was found earlier that the projected date of shelf space exhaustion was not associated with usage levels. In fact, table 23 confirms that there is actually a slight negative relationship between the availability of collection growth space and usage levels, although it is not statistically significant. However, the quality of collection storage space is a factor influencing usage that is significant at the $p=.026$ level. It appears that elements other than shelf capacity (location, convenience to user seating, attractiveness, etc.) influence usage. This finding indicates that the quality of access to print collections is still a consideration affecting student usage of library buildings.

Interestingly, the availability of wireless network access was not correlated with postproject usage, contrary to expectations from the chi-square analysis. In fact, the Pearson's $r$ for this variable was slightly negative. The percentage of wireless seats also was not significantly associated with usage after project completion.

The quality of artificial lighting and the number of group study rooms in the facility were likewise not related to postoccupancy usage. However, despite the absence of a significant correlation, the investigators encourage attention to these building components in academic library design. 


\section{Conclusions and Significance}

This study has compared preproject and postcompletion facility usage patterns for major library projects completed between 1995 and 2002. The investigators received Web survey responses to a 68-item survey from 182 of 357 libraries finishing facility projects covering at least 20,000 square feet. Using changes in before-and-after-project exit count data as their dependent variables, the researchers were able to distinguish key project characteristics associated with significant increases in facility usage from facility features less associated with postoccupancy usage growth.

\section{Major Conclusions}

The investigators found that 80 percent of the libraries completing a major space improvement project between 1995 and 2002 experienced greater facility usage in 20012002 than they did in a preproject baseline year, whereas 20 percent of the responding libraries reported lesser usage. The median change in postoccupancy usage was a 37.4 percent increase. In some instances, usage grew dramatically, with eight libraries reporting postoccupancy usage gains exceeding 200 percent and 25.6 percent experiencing increases of 100 percent or greater. Nine of the eighteen "decliners" reported usage reductions of less than 10 percent in the most recent fiscal year. One institution recorded a confirmed usage increase of 1012 percent.

In addition to finding a general pattern of greater library usage following project completion, the investigators identified a number of specific facility attributes associated with postproject usage gains, including:

- number of data ports;

- percentage of seats with wired network access;

- number and quality of public access computers;

- quality of library instruction lab;

- quality of telecommunication infrastructure;

- quality of natural lighting;

- quality of user work spaces;

- quality of layout (including location of service points);
- quality of collection storage space;

- quality of HVAC system;

- quality of overall facility ambience.

The study further confirmed that nearly all $(93.1 \%)$ of the private institutions completing library projects experienced postoccupancy usage increases, whereas 73.8 percent of the public institutions reported greater usage. In addition, there was a tendency for projects completed during the latter part of the study period to experience more consistent usage gains than projects completed between 1995 and 1998.

Several key variables did not have a demonstrable impact on postcompletion usage increases. Expected associations between specific facility/institutional features and growth in facility use were not found for the following variables:

- type of project (new versus expanded or renovated);

- campus location;

- presence of nonlibrary units in general;

- presence of high-end wiring system;

- presence or coverage of wireless communication systems;

- number of group study rooms;

- presence of general computer labs;

- cybercafes or snack bars;

- long-term shelving capacity for print collection growth.

Although group study rooms and wireless systems were not associated with increased facility use in this study, the investigators are not recommending that they be given a diminished priority in facility planning.

\section{Significance}

Discussions about the "library as place" often occur in a context of speculation uninformed by validated empirical evidence. This study addresses that research gap by providing a series of findings about the impact of new and improved library spaces on use of the physical facility, as measured by exit count data.

Although statistical summaries from major library associations indicate generally decreased levels of collection, refer- 
ence, and building usage, this study confirms that the great majority of new and improved libraries have experienced sustained increases in usage of the physical facility following project completion. In addition, some libraries have experienced profound increases in usage, with 25.6 percent of survey participants reporting postproject usage gains exceeding 100 percent. In short, a high-quality building does make a difference, and students continue to use an improved facility even after the novelty of a new library has worn off.

This study also has identified specific facility and institutional variables associated with higher levels of postoccupancy usage. By knowing what facility features are most likely to produce usage increases, facility planners can better design libraries likely to attract students and advance the academic mission of the institution. Moreover, they can better determine which features are most important to retain in "value engineering," when budget limitations require that facility features be eliminated or scaled back. Although the investigators urge that the results not be used rigidly to include or exclude certain facilities (group study rooms or cybercafes, for example), they do provide general guidelines for identifying facility features most likely to yield expanded library usage.

It also is clear from this study that students are not uniformly "deserting" academic libraries. Rather, they may be making less use of older facilities lacking good computers, an extensive network access infrastructure for laptop computer users, and a comfortable environment conducive to a variety of uses (individual and study research, instruction, social). With a median 37.4 percent increase in postproject usage, new and improved libraries are clearly not experiencing declines in usage of the physical facility. Instead, they are encountering a pattern of usage growth that runs counter to the declines reported in some articles and data compilations.

Although the study did not address the specific types of use occurring in improved facilities, it provides clear, empirical evidence that students can and will use a comfortable, well-equipped library, even with remote access to many electronic databases and the Internet available. This is an important conclusion because it suggests that a discerning investment in library facility improvementswhether a new library or improvements to existing space-will attract students to a specialized physical place designed to provide research and study space, teach information literacy skills, expose students to recorded knowledge in both print and electronic formats, and make "information experts" readily accessible.

Academic libraries will continue to compete with other campus units for scarce capital project, technology, staffing, and other funds. However, this article provides valid, empirical evidence that well-planned, contemporary libraries are still used heavily in an era of rapid technological change. It also provides findings important for planning facilities likely to attract student users well into the future.

Ultimately, decisions on the future of academic library space will reflect changes in technology, institutional priorities, teaching strategies, and librarians' own assessments of the significance of the physical library. As Donald E. Riggs has noted, "the belief that 'everything is going to be online' influences decision makers not to fund requests for new libraries. ${ }^{\prime 9}$ In the meantime, the findings in this article should move the "library as place" debate beyond the anecdotal level, provide some guideposts for strategic facility planning, and demonstrate that welldesigned libraries remain essential as flexible, evolving, and relevant learning centers in an increasingly decentralized information environment.

\section{Implications for Further Research}

Although this study examines many variables affecting facility usage following project completion, it does not address a variety of other issues in the building-usage relationship that merit further study. Several such issues are identified below:

1. As the library provides greater access to e-journals and e-books, how will 
users secure access to and use those resources? In short, to what extent will they use the physical library as a portal to those materials?

2. What specific uses (research, study, social, other) are students making of library facilities today? How will those usage patterns change over time?

3. How are student attitudes toward the physical library as a social institution changing? How will those attitudes affect subsequent student behaviors?

4. Is there any difference in physical facility use between students receiving library instruction and those not receiving it? Do usage patterns differ by discipline or academic level (freshman versus master's, for example)?

5. How do commuting and residential students use the physical library?

6. Do curriculum changes (new programs, writing requirements, etc.) affect usage of the physical library?

7. Do non-site-specific library services (document delivery, virtual reference, etc.) affect use of the library building?

8. Are older libraries (pre-1980, for example) used differently from those built in recent years?

9. To what extent does the inclusion of specific nonlibrary facilities (computer labs versus writing centers, for example) affect various uses of the library building?

10.Do students making use of nonlibrary facilities under the same roof use the library differently from students not utilizing those services?

11. Does the creation of an Information Commons or the provision of productivity software on library computers affect building use?

These issues are merely suggestive of a broader range of research questions involving use of the physical library in a changing environment. The investigators anticipate that the current study will stimulate further research into the use of library buildings, thereby giving librarians and planners a sound base of empirical evidence for understanding emerging usage patterns and creating physical "places" that will effectively address future library space requirements.

\section{Notes}

1. For a detailed discussion of current, recent, and planned projects in the California State University system, see Gordon Smith, "Libraries for the $21^{\text {st }}$ Century," Newsletter of the California State University Libraries 2 (fall 2003): 1-8. Available online from http:/ / www.calstate.edu/LS/ Fall2003.pdf. [Cited 4 December 2003].

2. Harold B. Shill and Shawn Tonner, "Creating a Better Place: Physical Improvements in Academic Libraries, 1995-2002," College \& Research Libraries 64 (Nov. 2003): 431-66.

3. Scott Carlson, "The Deserted Library," Chronicle of Higher Education 48 (Nov. 16, 2001): A35-38.

4. Scott Bennett, Libraries Designed for Learning (Washington, D.C.: Council on Library and Information Resources, 2003).

5. Virginia Kelsh, "USF Law Library," e-mail to Harold B. Shill, Feb. 10, 2003.

6. Comprehensive Carnegie classification listings are available online at the Carnegie Foundation for the Advancement of Teaching Web site: http:/ / www.carnegiefoundation.org.

7. The Pennsylvania State University, Faculty Advisory Committee on Academic Computing, "FACAC Student Survey 2002" (University Park, Pa.: The Pennsylvania State University, 2002).

8. For a discussion of the political advantages of strategically selected partnerships, see Harold B. Shill, "Strategic Positioning and the Building Project: Penn State Harrisburg's Library of the Future," in Racing toward Tomorrow: Proceedings of the Ninth National Conference of the Association of College $\mathcal{E}$ Research Libraries, ed. Hugh A. Thompson (Chicago: Association of College \& Research Libraries, 1999), 370-79.

9. Donald E. Riggs, "New Libraries Remain an Excellent Investment," College E Research Libraries 63 (Mar. 2002): 109. 